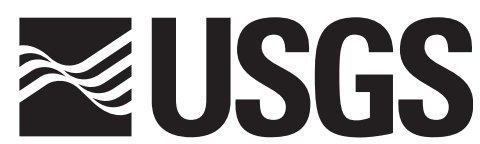

science for a changing world

\title{
The Iron Hill (Powderhorn) Carbonatite Complex, Gunnison County, Colorado-A Potential Source of Several Uncommon Mineral Resources
}

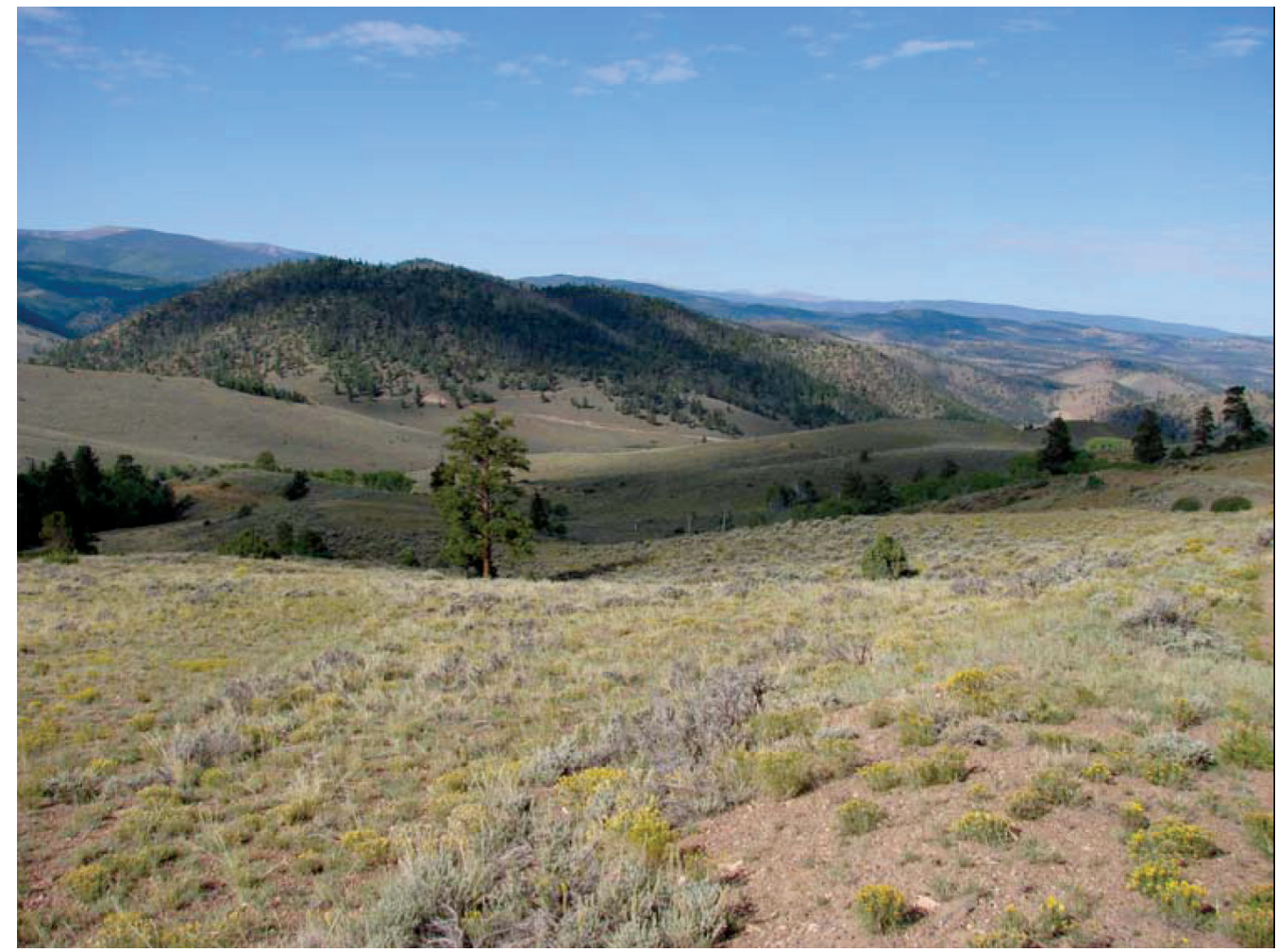

Open-File Report 2009-1005 


\title{
U.S. Department of the Interior DIRK KEMPTHORNE, Secretary
}

\author{
U.S. Geological Survey \\ Mark D. Myers, Director
}

U.S. Geological Survey, Reston, Virginia: 2009

This and other USGS information products are available at http://store.usgs.gov/
U.S. Geological Survey
Box 25286, Denver Federal Center
Denver, CO 80225
To learn about the USGS and its information products visit http://www.usgs.gov/
1-888-ASK-USGS

Any use of trade, product, or firm names is for descriptive purposes only and does not imply endorsement by the U.S. Government.

Although this report is in the public domain, permission must be secured from the individual copyright owners to reproduce any copyrighted materials contained within this report.

Suggested citation:

Van Gosen, B.S., 2009, The Iron Hill (Powderhorn) carbonatite complex, Gunnison County, Colorado—A potential source of several uncommon mineral resources: U.S. Geological Survey Open-File Report 2009-1005, 28 p. 


\section{\#USGS \\ science for a changing world}

The Iron Hill (Powderhorn) Carbonatite Complex, Gunnison County, Colorado-A Potential Source of Several Uncommon Mineral Resources

By Bradley S. Van Gosen

Open-File Report 2009-1005

U.S. Department of the Interior

U.S. Geological Survey 


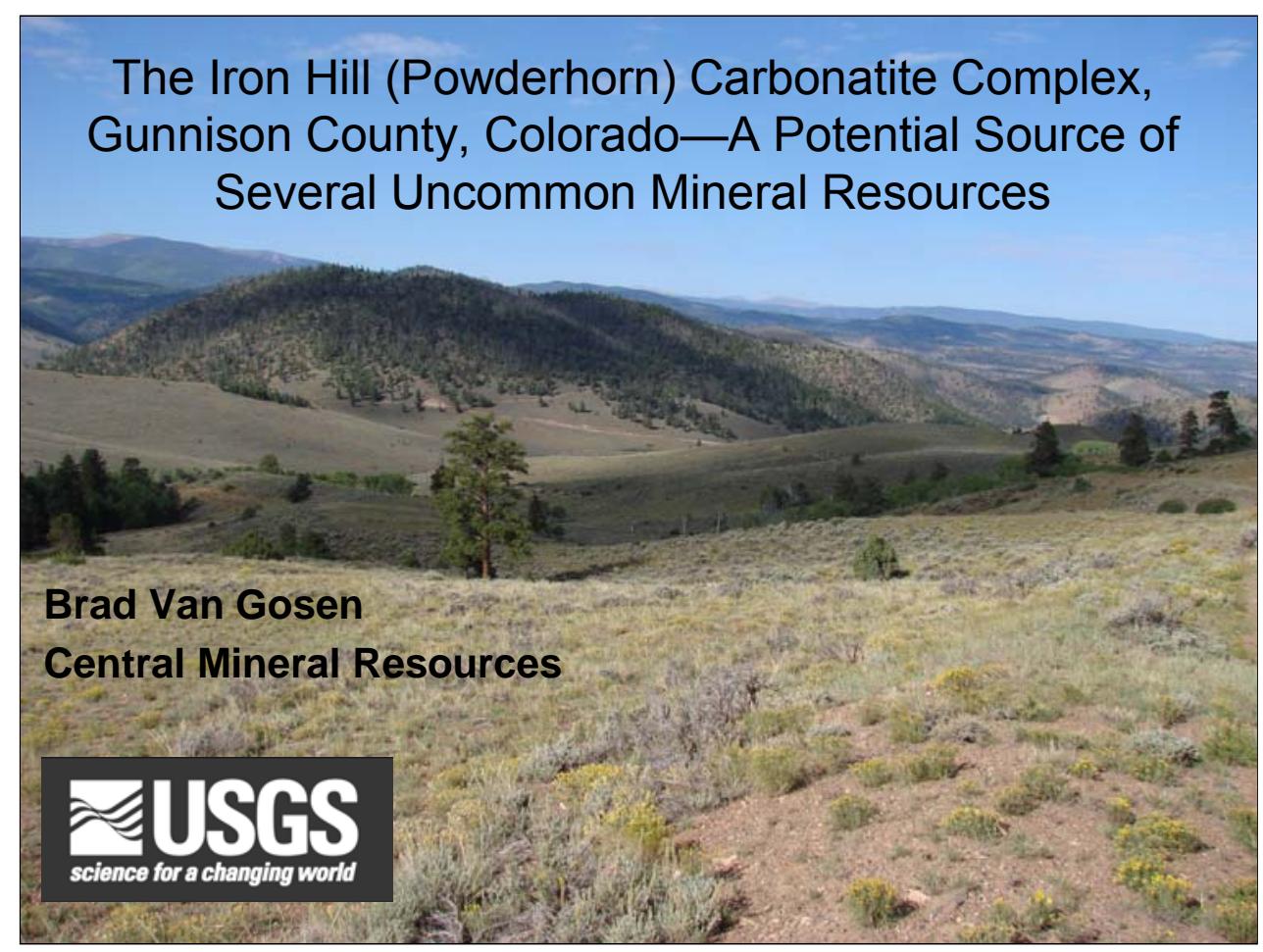

\section{Introduction}

A similar version of this slide show was presented on three occasions during 2008: two times to local chapters of the Society for Mining, Metallurgy, and Exploration (SME), as part of SME's Henry Krumb lecture series, and the third time at the Northwest Mining Association's 114th Annual Meeting, held December 1-5, 2008, in Sparks (Reno), Nevada.

In 2006, the U.S. Geological Survey (USGS) initiated a study of the diverse and uncommon mineral resources associated with carbonatites and associated alkaline igneous rocks. Most of these deposit types have not been studied by the USGS during the last 25 years, and many of these mineral resources have important applications in modern technology.

The author chose to begin this study at Iron Hill in southwestern Colorado (visible in this view) because it is the site of a classic carbonatite complex, which is thought to host the largest known resources of titanium and niobium in the United States. 
- Carbonatite: An igneous carbonate rock.

-Thought to be formed by partial melting of peridotites in the upper mantle

-Alkaline igneous rocks:

-Formed from magmas and fluids enriched in alkalies, precipitating $\mathrm{Na}$ - and $\mathrm{K}$-bearing minerals not usually found in "normal" igneous rocks.

- Igneous rocks undersaturated in silica, which therefore contain little or no quartz.

\section{Terminology for Background Information}

Carbonatites: Rare intrusive or extrusive carbonate igneous rocks that are formed by magmatic or metasomatic processes. Carbonatites usually consist of 50 percent or more (by volume) primary carbonate minerals, such as calcite, dolomite, and (or) ankerite. They are genetically associated with, and therefore typically occur near, alkaline igneous rocks. The carbonate minerals in carbonatites do not form due to alteration processes; rather, carbonatites crystallize from a magma that is super-saturated in calcium and carbon dioxide. Several theories have been advanced to explain the genesis of carbonatites. The most popular theory is that carbonatites form due to partial melting of peridotites in the upper mantle of the Earth.

Alkaline igneous rocks: A series of igneous rocks formed from magmas and fluids so enriched in alkalies that sodium- and potassium-bearing minerals form constituents of the rock in much greater proportion than in "normal" igneous rocks. Alkaline igneous rocks-sometimes referred to as "alkalic rocks"-are characterized by feldspathoid minerals and (or) alkali pyroxenes and amphiboles. 


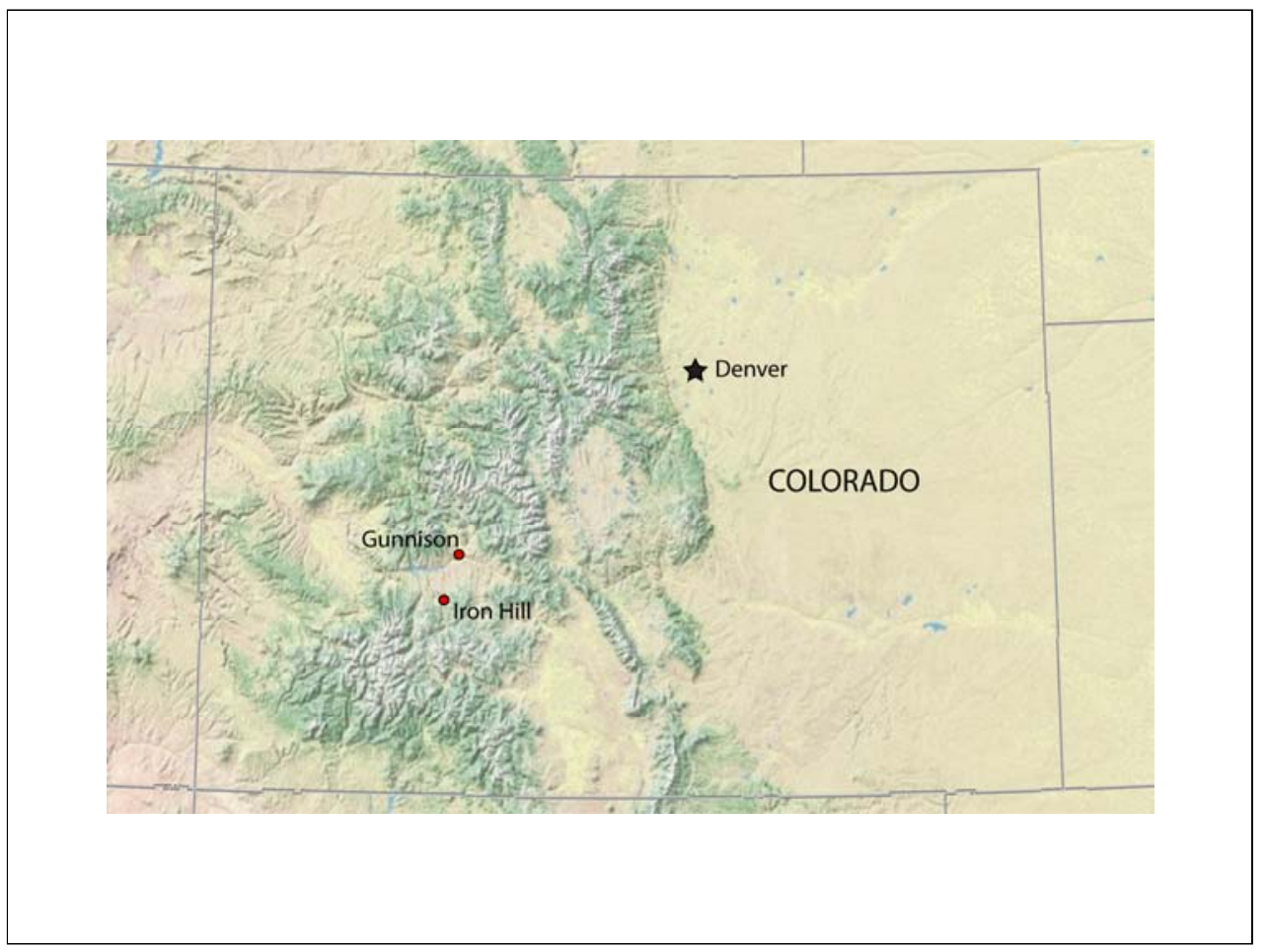

Iron Hill is located near the small settlement of Powderhorn, about $22 \mathrm{mi}$ (35 km) south-southwest of Gunnison, Colorado. 


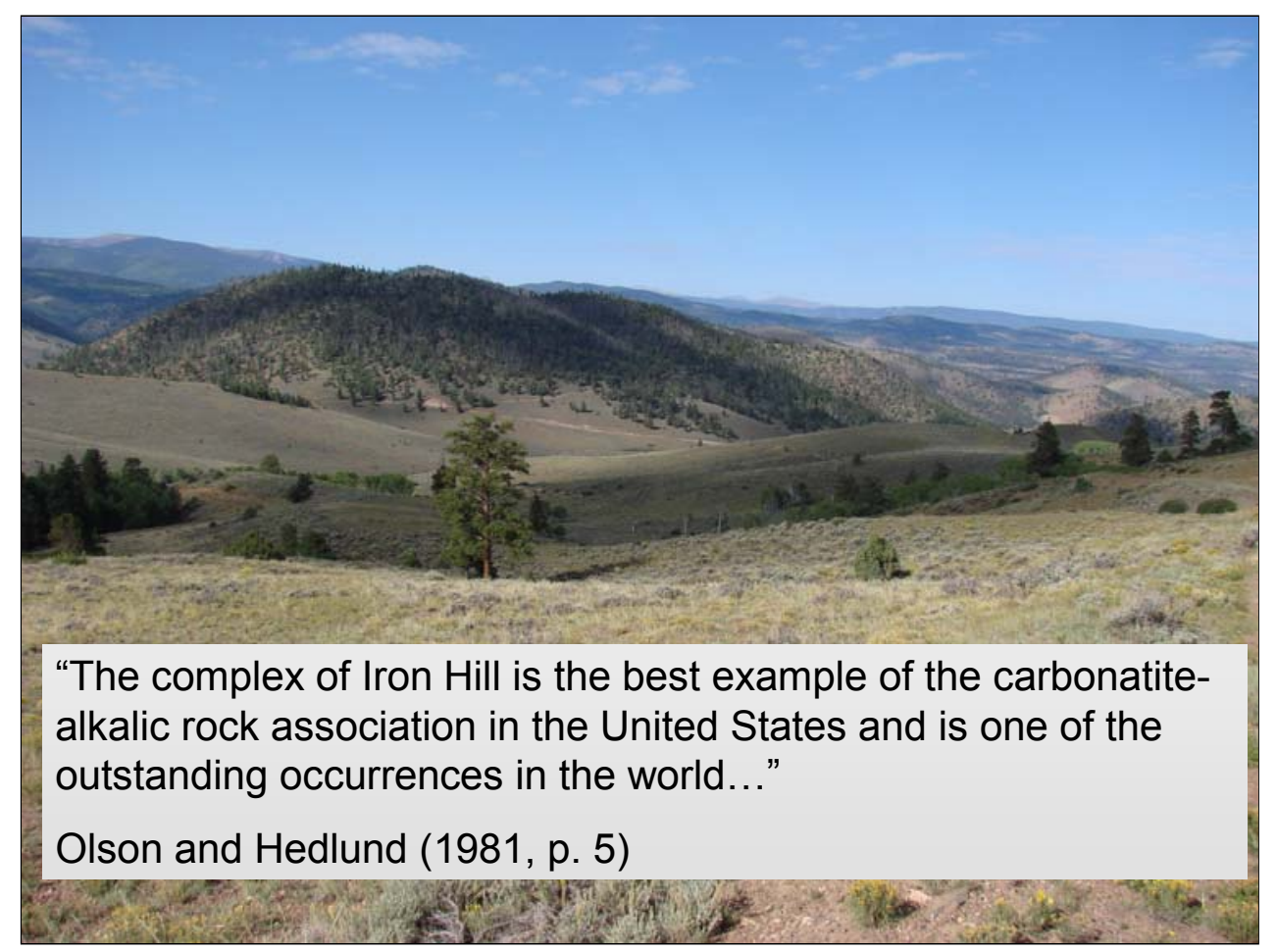

\section{Discussion}

Olson and Hedlund (1981, p. 5) appropriately described the Iron Hill carbonatite complex as " ...the best example of the carbonatite-alkalic rock association in the United States and is one of the outstanding occurrences in the world, comparable to many of the classic areas in Africa and other continents."

Iron Hill is the elongate tree-covered hill in the center of this southwest-facing view. The hill is composed entirely of a carbonatite stock. The area that lies between the photographer's viewpoint and Iron Hill in the distance is underlain by a series of unusual alkaline igneous rocks. 


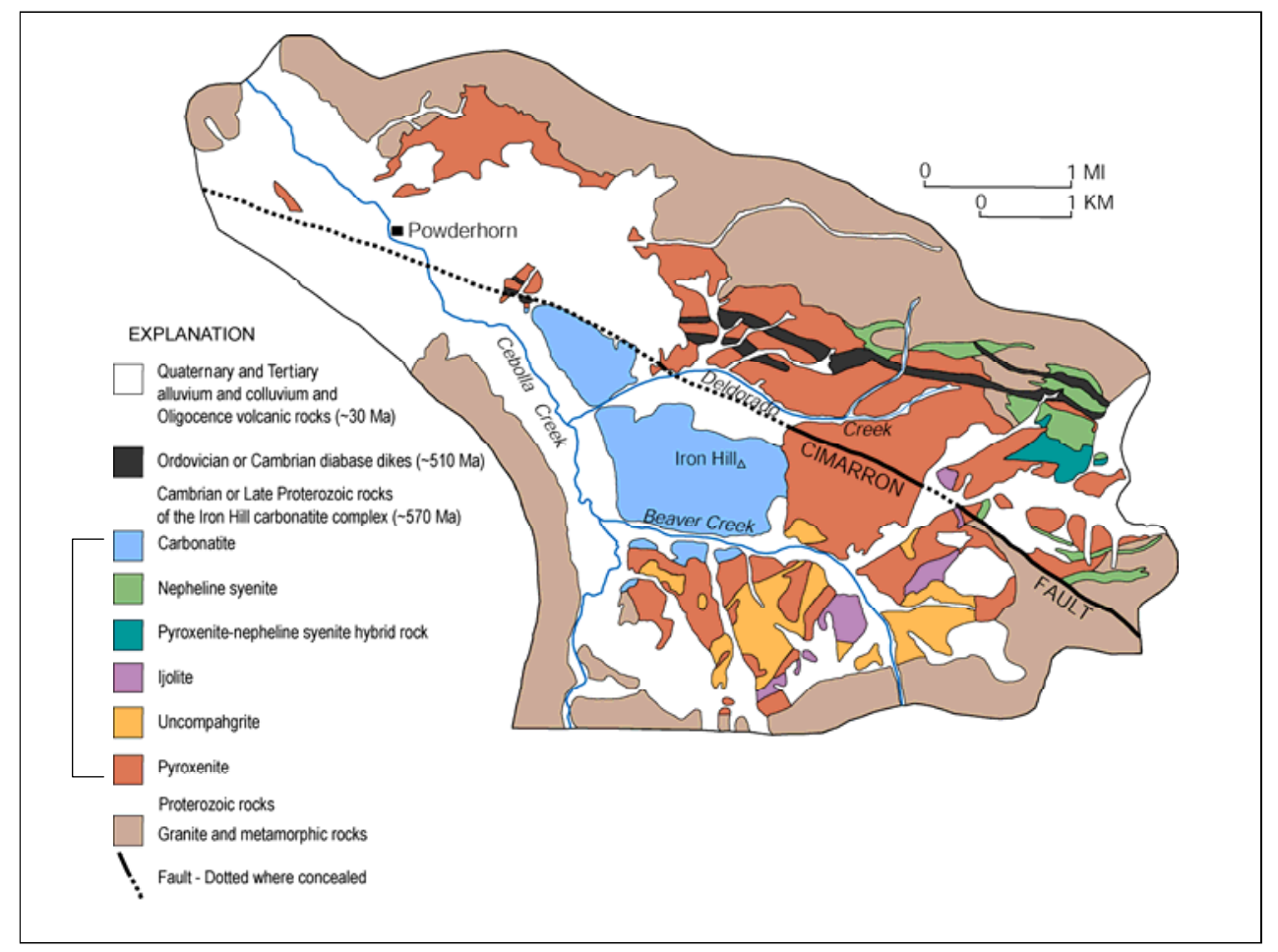

This geologic map of the Iron Hill carbonatite complex was generalized from the geologic maps of Olson (1974) and Hedlund and Olson (1975).

About $570 \mathrm{Ma}$, the Iron Hill (carbonatite) complex intruded into Proterozoic granite and metamorphic rocks. The Iron Hill complex, from oldest unit to youngest, consists of pyroxenite, uncompahgrite, ijolite, a pyroxenite-nepheline syenite hybrid (mixed) rock, nepheline syenite, and a carbonatite stock. The pyroxenite unit (described in subsequent slides) is the most mafic rock unit and was the first intrusive phase of the complex. The pyroxenite was followed by the intrusion of uncompahgrite, an unusual alkaline igneous rock composed mainly of minerals of the melilite group and pyroxenes. Next to intrude was another unusual alkaline rock type called "ijolite," which is composed primarily of pyroxene and nepheline. This was followed by the intrusion of a nepheline syenite phase in the northeastern part of the complex; the nepheline syenite is composed of about 75 percent potassium feldspar with accessory nepheline. The last major phase of the Iron Hill complex was the intrusion of the carbonatite stock (described in subsequent slides).

About 60 million years later, at about $510 \mathrm{Ma}$, the northern part of the complex was intruded by diabase (gabbro) dikes.

About $30 \mathrm{Ma}$, during eruptions of the nearby San Juan volcanic field, much of the complex was covered by volcanic rocks.

Recent erosion has removed most of the volcanic rocks that once covered the Iron Hill complex, exposing much of the bedrock of the intrusive complex.

The Cimarron fault zone offsets rocks north of the fault upward relative to the rocks in the southern block of the fault. As a result, rocks of the complex exposed on the north side of the Cimarron fault zone generally represent deeper levels of the intrusive complex compared to those exposed south of the fault. 


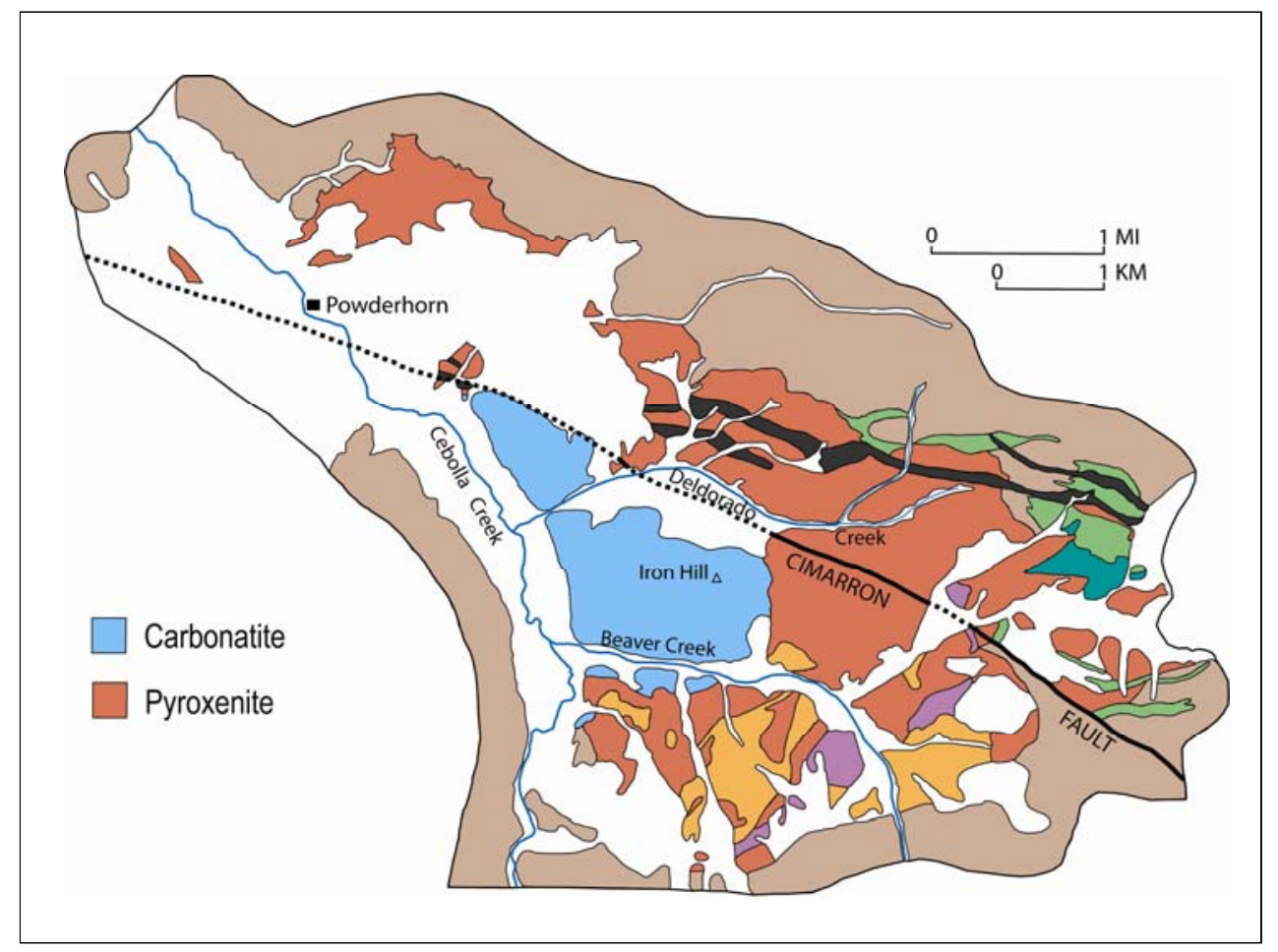

Two major rock units in the Iron Hill complex appear to have significant mineral resource potential: (1) the carbonatite stock, the last major phase of the complex, and (2) the pyroxenite unit, the first and most mafic phase of the complex.

In the late 1800 s, the pyroxenite unit was recognized as a significant iron deposit by the railroad companies that were seeking sources of iron to assist in their expansion of the railroad system into the West. However, the high titanium content of the pyroxenite presented difficulties for the smelting methods of that time. 


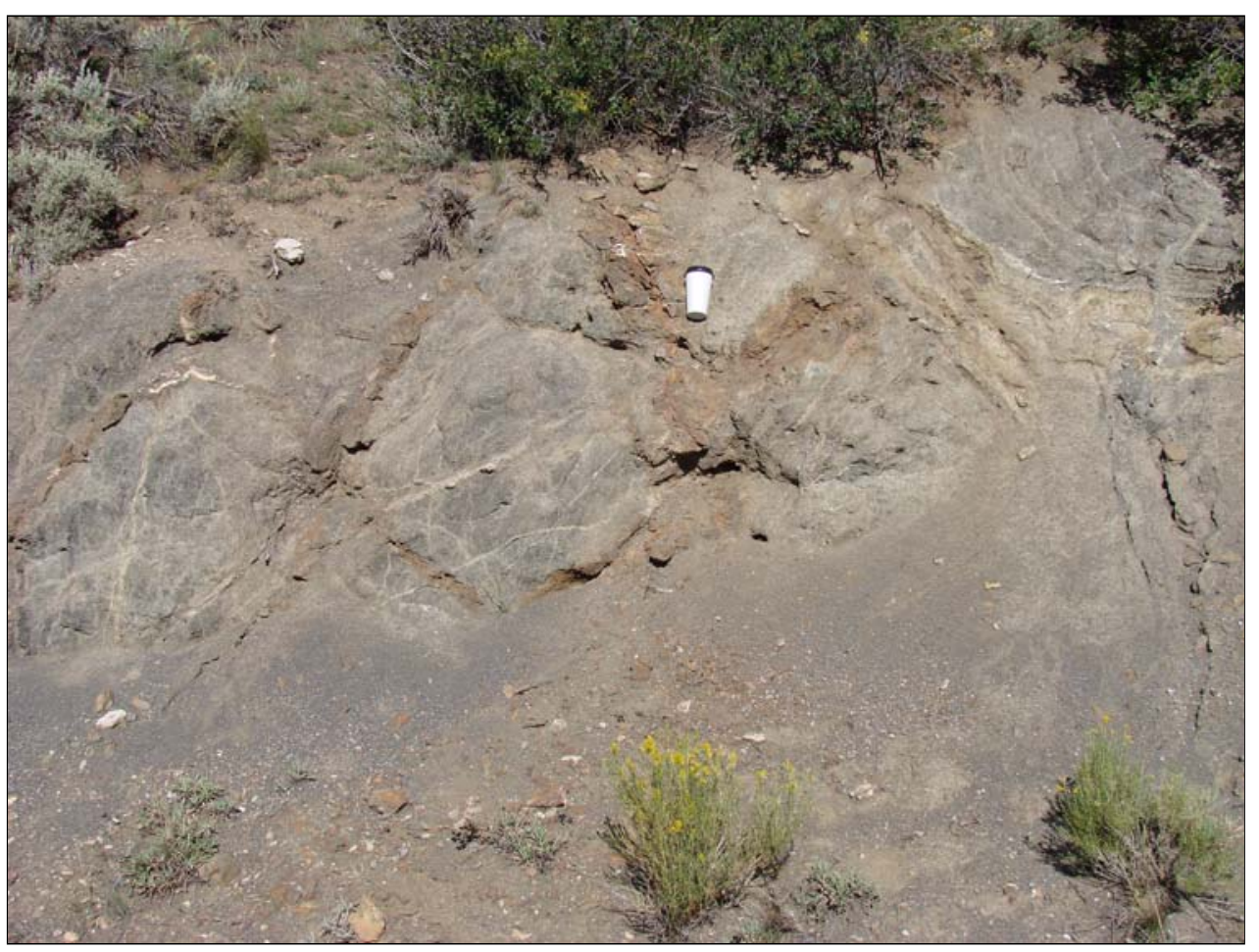

The pyroxenite unit, shown here, weathers readily and crumbles in your hand. Suggestions of layering (upper right) common throughout the pyroxenite unit provide evidence that multiple pulses of magma contributed to the formation of this rock unit. The pyroxenite unit is often crisscrossed by numerous discontinuous carbonatite veins and thin dikes. 


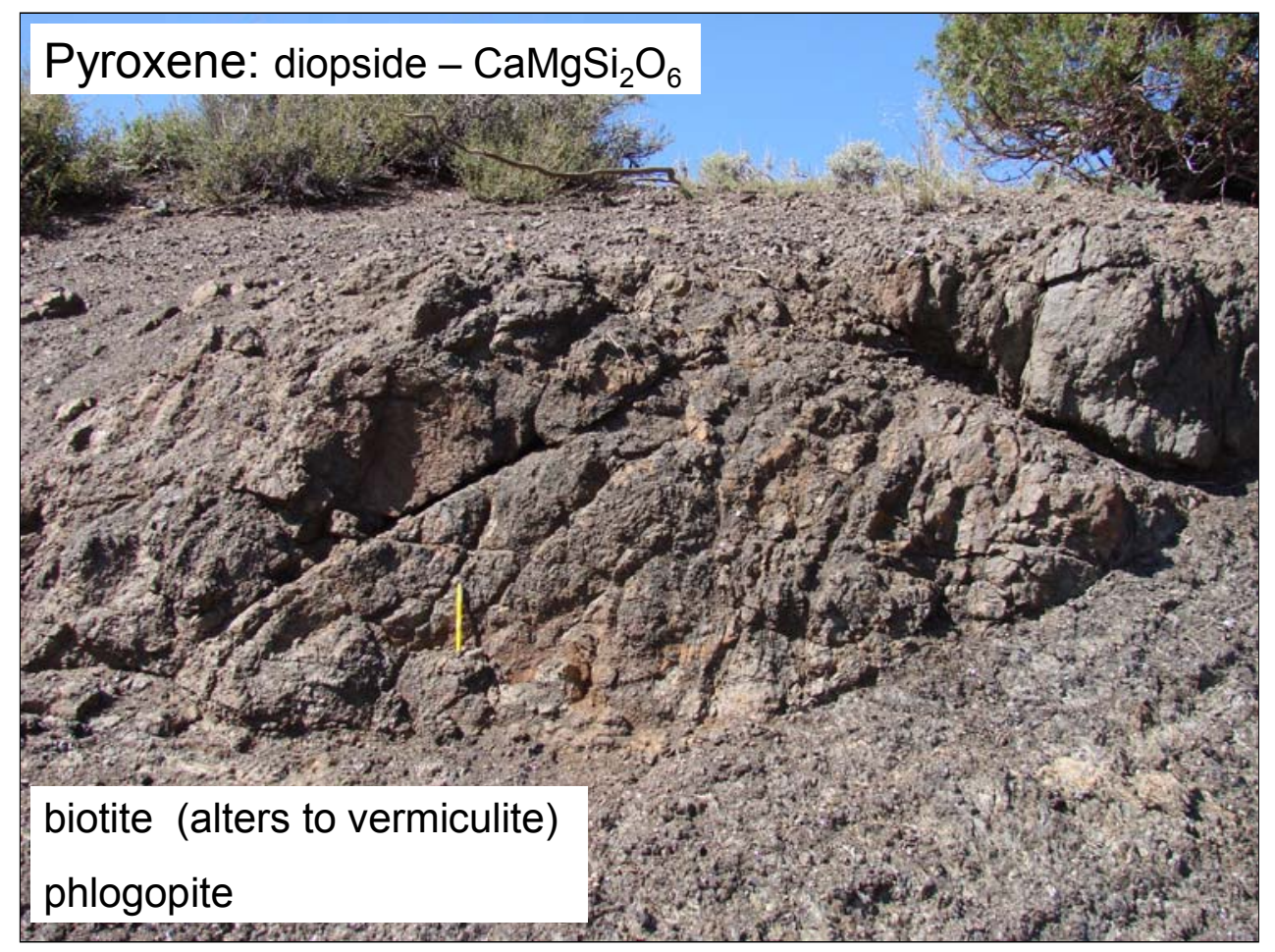

The primary pyroxene in the pyroxenite of Iron Hill is diopside, a calcium-rich pyroxene. The rock also contains a considerable amount of mica, as biotite and phlogopite, which have weathered and altered in surface and near-surface intervals to form pod-like deposits of vermiculite. 


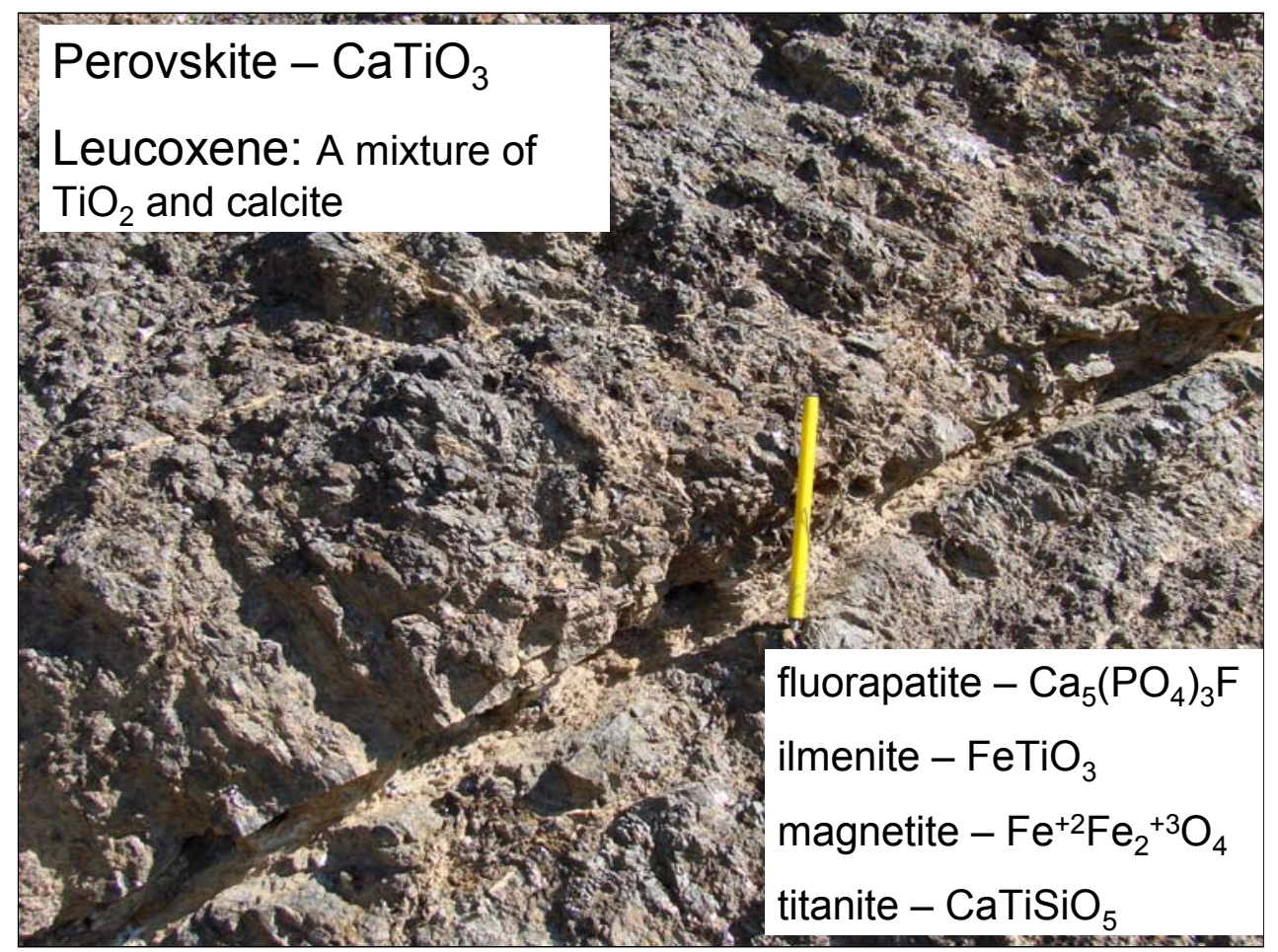

An important accessory mineral of the pyroxenite is perovskite, a calciumtitanium-oxide mineral. The perovskite alters to form the mineral leucoxene, which is a mixture of titanium-oxide and calcite. Accessory minerals in the pyroxenite include fluorapatite, ilmenite, magnetite, and titanite. This mineral assemblage (except for the fluorapatite) explains the high iron and titanium content of the pyroxenite unit. 


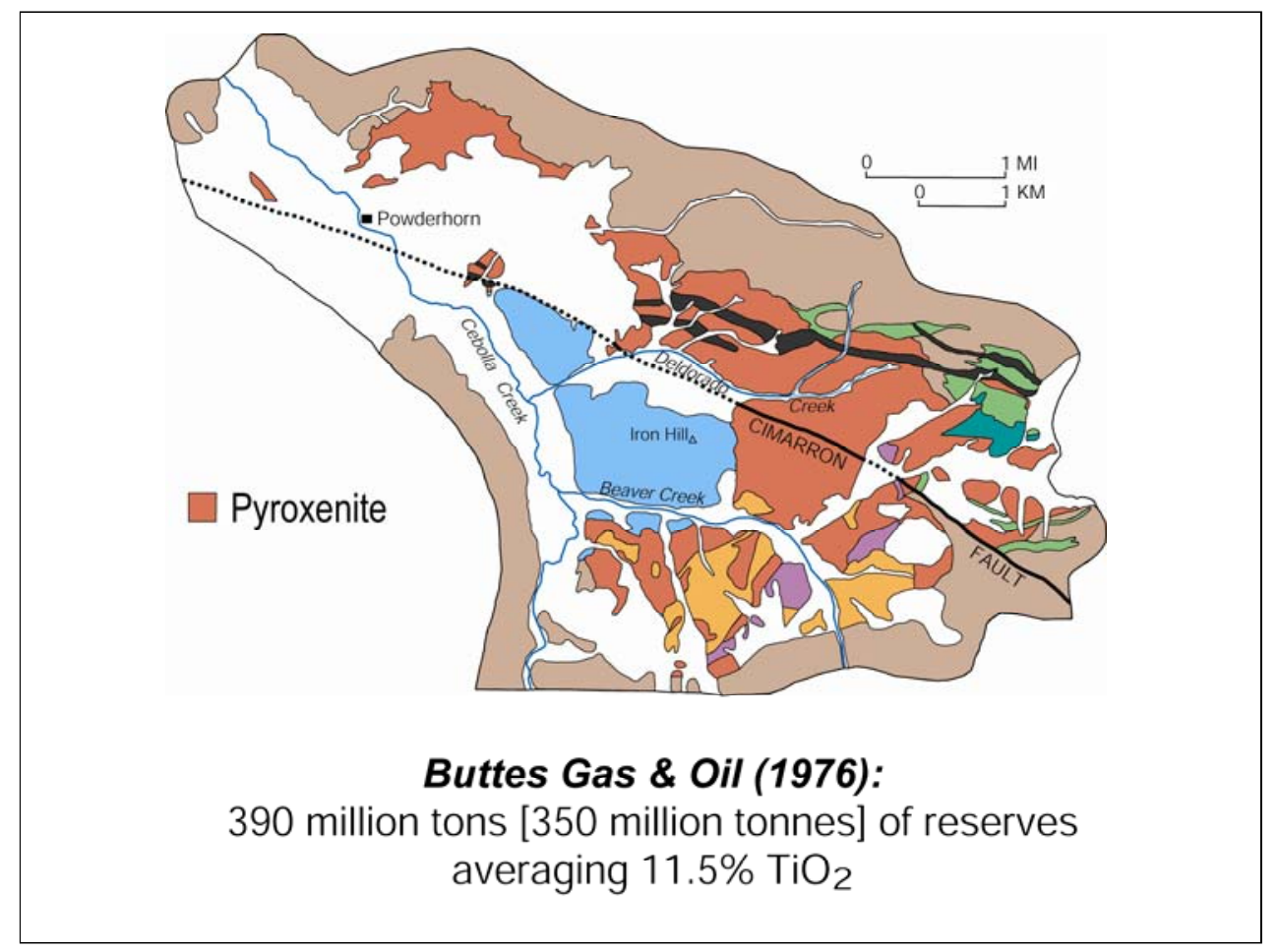

During the 1960s, 1970s, and 1980s, Buttes Gas \& Oil conducted considerable exploration within the pyroxenite unit of the Iron Hill complex to determine its titanium resource potential. Their exploration included core drilling of the pyroxenite, particularly in areas north of the Cimarron fault zone. They estimated that the pyroxenite unit of the north block of the fault zone contains about 390 million short tons (350 million metric tons) of reserves with an average grade of 11.5 percent titanium oxide. 


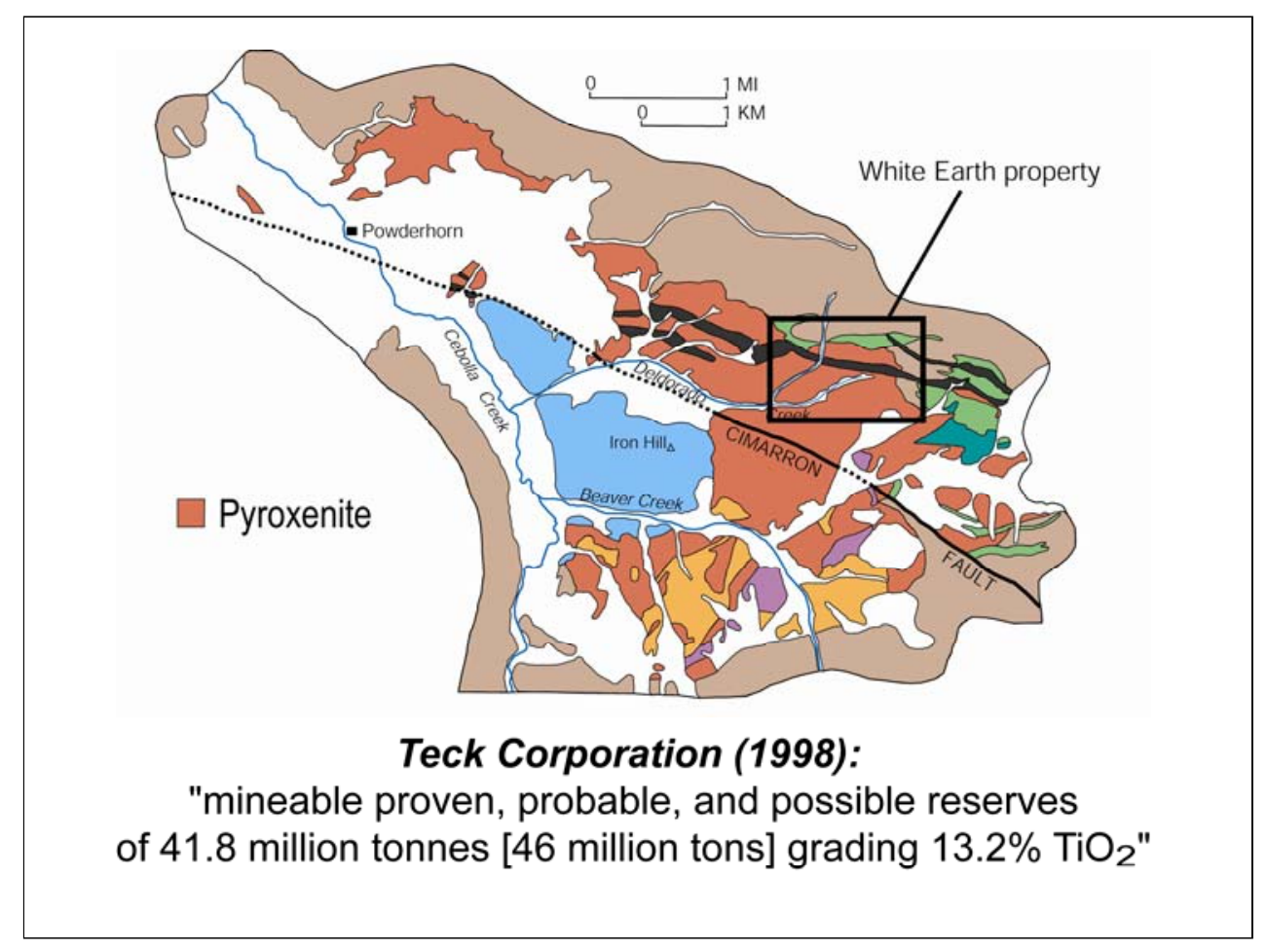

In 1990, Teck Corporation formed a joint venture relationship with Buttes Gas \& Oil to jointly evaluate the titanium resources of the Iron Hill pyroxenites. In 1994, Teck Corporation purchased 100 percent interest in the claim properties at Iron Hill, which they hold today (in 2008) under the ownership of Teck Cominco Limited.

Teck Corporation identified an area within the northeastern part of the pyroxenite unit that they suggested has the highest perovskite content within the complex, and thus has the highest titanium content; they refer to this area as their White Earth property. In 1998, Teck Corporation suggested that the White Earth property contains mineable reserves of about 41.8 million metric tons (46 million short tons) grading 13.2 percent titanium oxide (Shaver and Lunceford, 1998). 


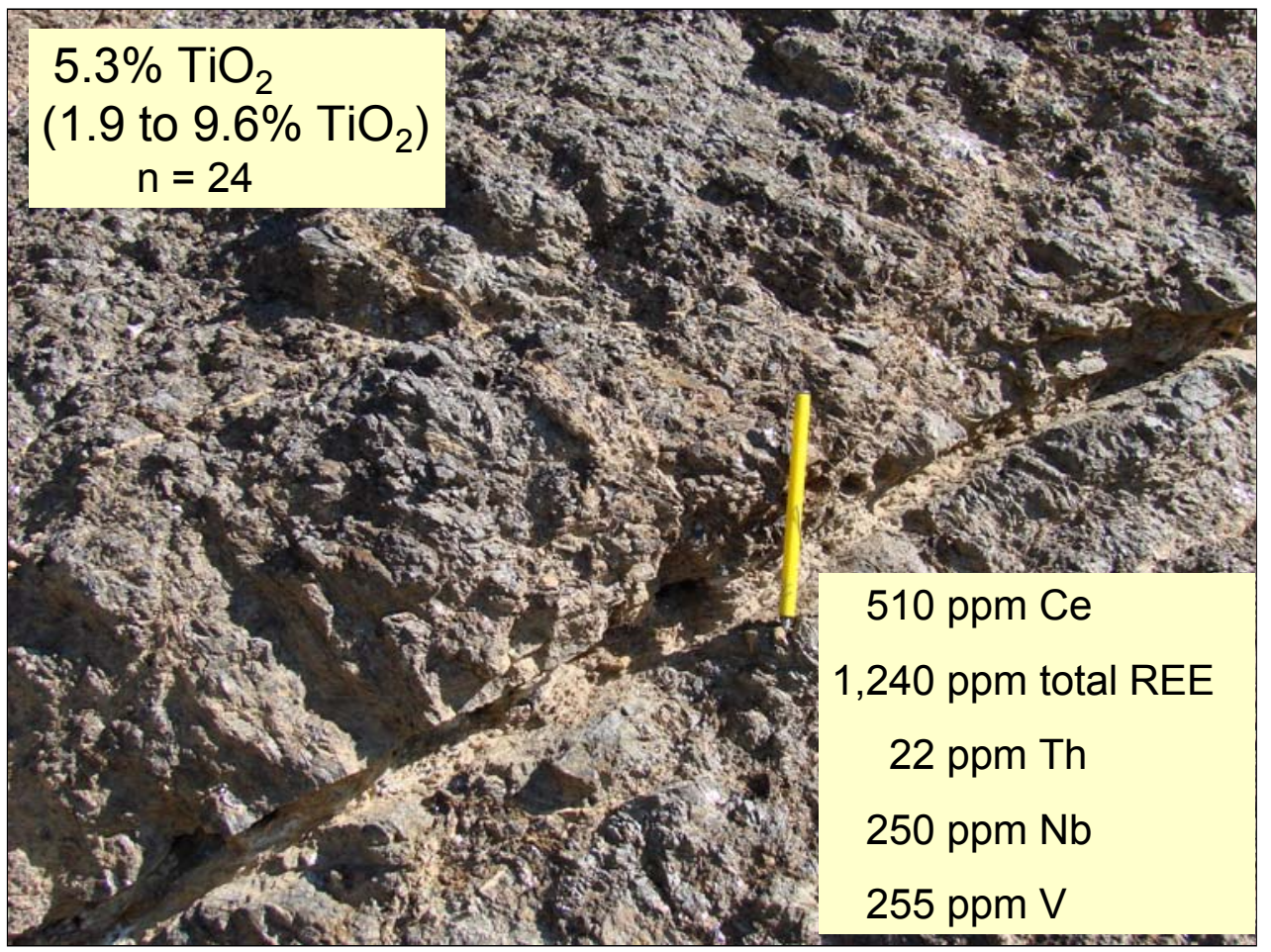

In 2006, the author collected 57 rock samples from nine types of intrusive rocks in the Iron Hill carbonatite complex (Van Gosen, 2008). This sample set included 24 widely scattered samples of the pyroxenite unit. The samples were analyzed for 55 major and trace elements using inductively coupled plasmaatomic emission spectrometry (ICP-AES) and inductively coupled plasmamass spectrometry (ICP-MS). Analyses of the 24 pyroxenite samples found a median value of 5.3 percent titanium oxide, with values ranging from 1.9 to 9.6 percent titanium oxide, and found median contents of 510 ppm (parts per million) cerium, 1,240 ppm total rare earth elements, 22 ppm thorium, 250 ppm niobium, and 255 ppm vanadium. 


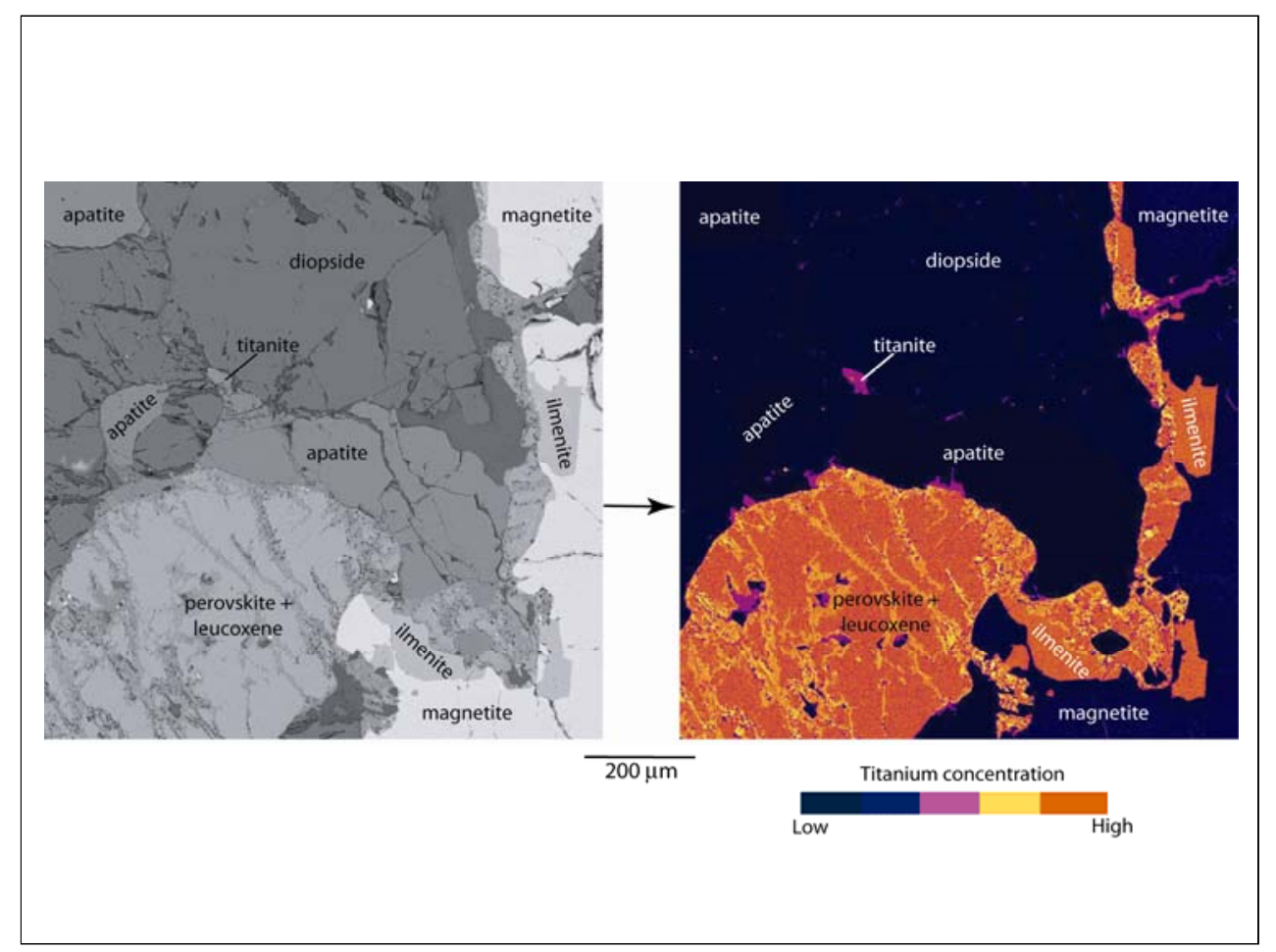

Paired electron backscattered image (left) and X-ray intensity map (right) showing the distribution of titanium in perovskite, leucoxene, ilmenite, and titanite in a pyroxenite from the northern part of the Iron Hill complex. Both images are shown at the same scale. 


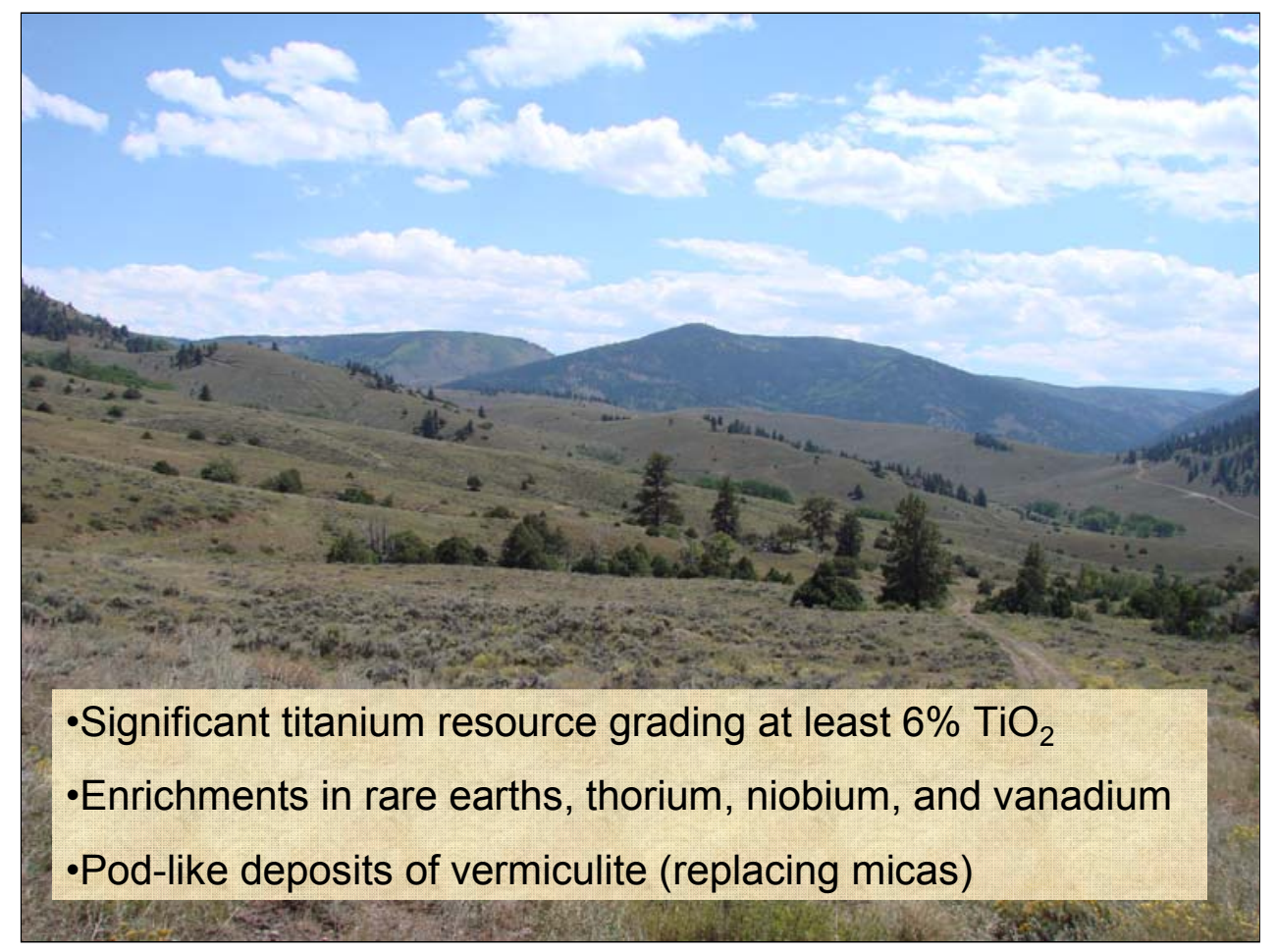

The area of low, sloping hills in the foreground of this southeast-facing view are formed by rocks of the northern part of the Iron Hill complex; these rocks lie north of the Cimarron fault zone. This area is composed primarily of pyroxenite and includes the White Earth property of Teck Cominco Limited. The pyroxenite of this area is thought to represent the largest known titanium resource in the United States (Shaver and Lunceford, 1998; Thompson, 1987).

The pyroxenite unit is also enriched in rare earth elements, thorium, niobium, and vanadium and contains pod-like deposits of vermiculite, which replaced biotite and phlogopite (micas) in surface and near-surface intervals. 


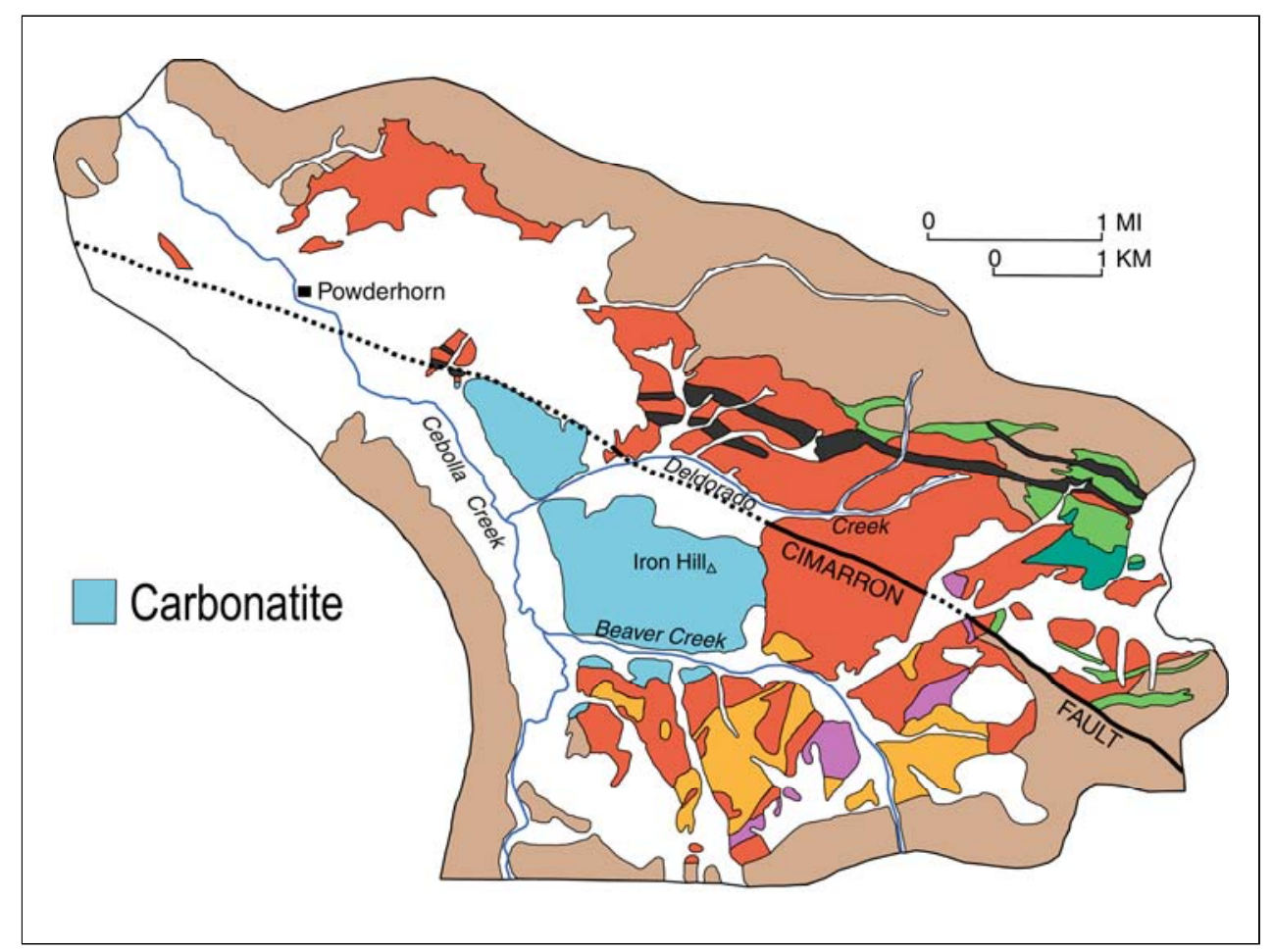

Another part of the Iron Hill complex that holds significant mineral resource potential is its carbonatite stock, which was the last major intrusive phase of the complex. Several hundred thin carbonatite dikes have also been mapped; these dikes transect all of the earlier formed igneous units of the intrusive complex. The carbonatite dikes are distributed in a generally radial pattern around the carbonatite stock, suggesting that they formed coincident (or nearly so) with the emplacement of the stock. 


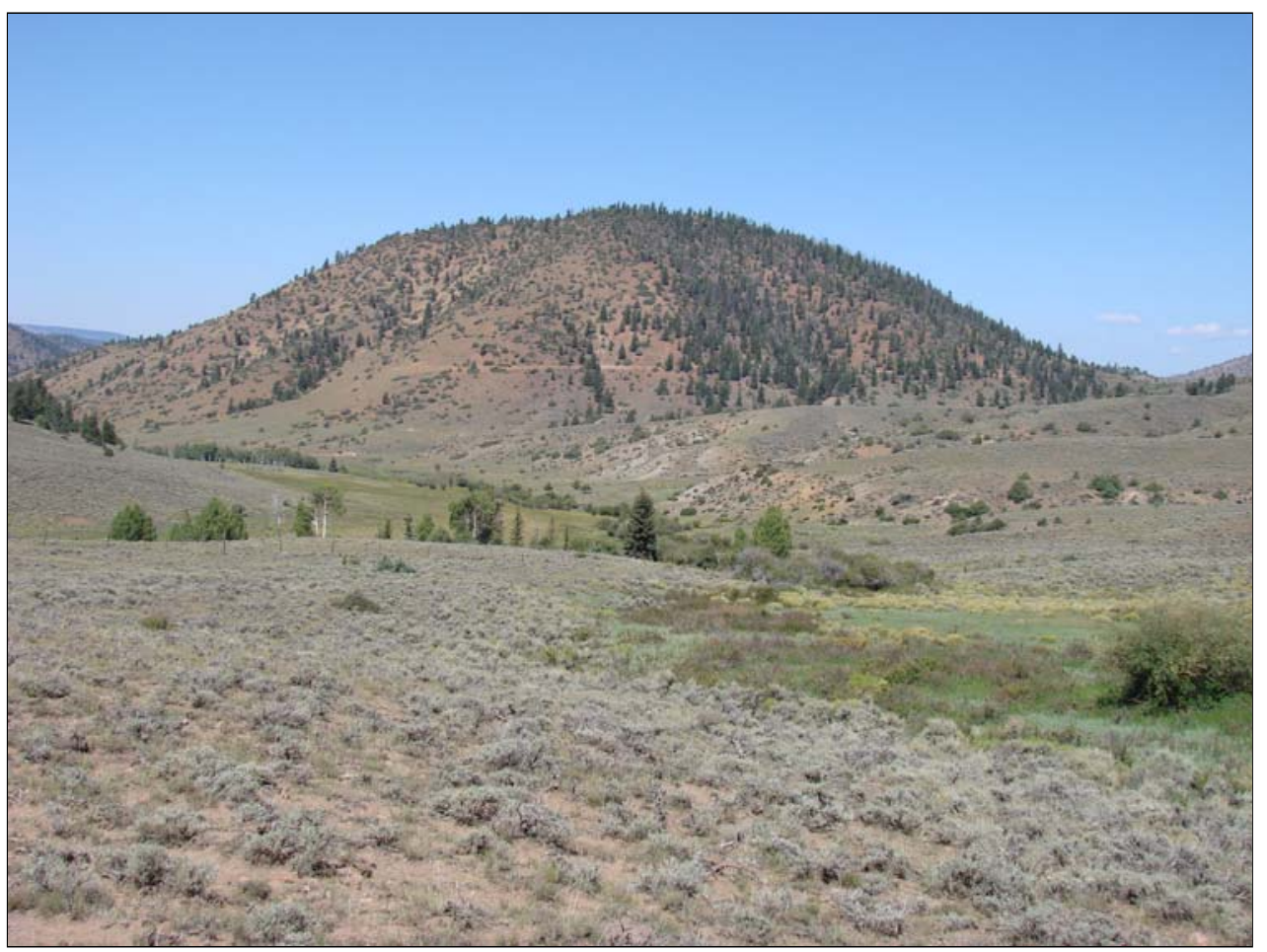

Iron Hill, viewed towards the northwest, is formed entirely by a carbonatite stock. This stock is the largest known exposed mass of carbonatite in the United States. The low hills in the foreground are primarily underlain by pyroxenite, along with small zones of uncompahgrite and ijolite. 


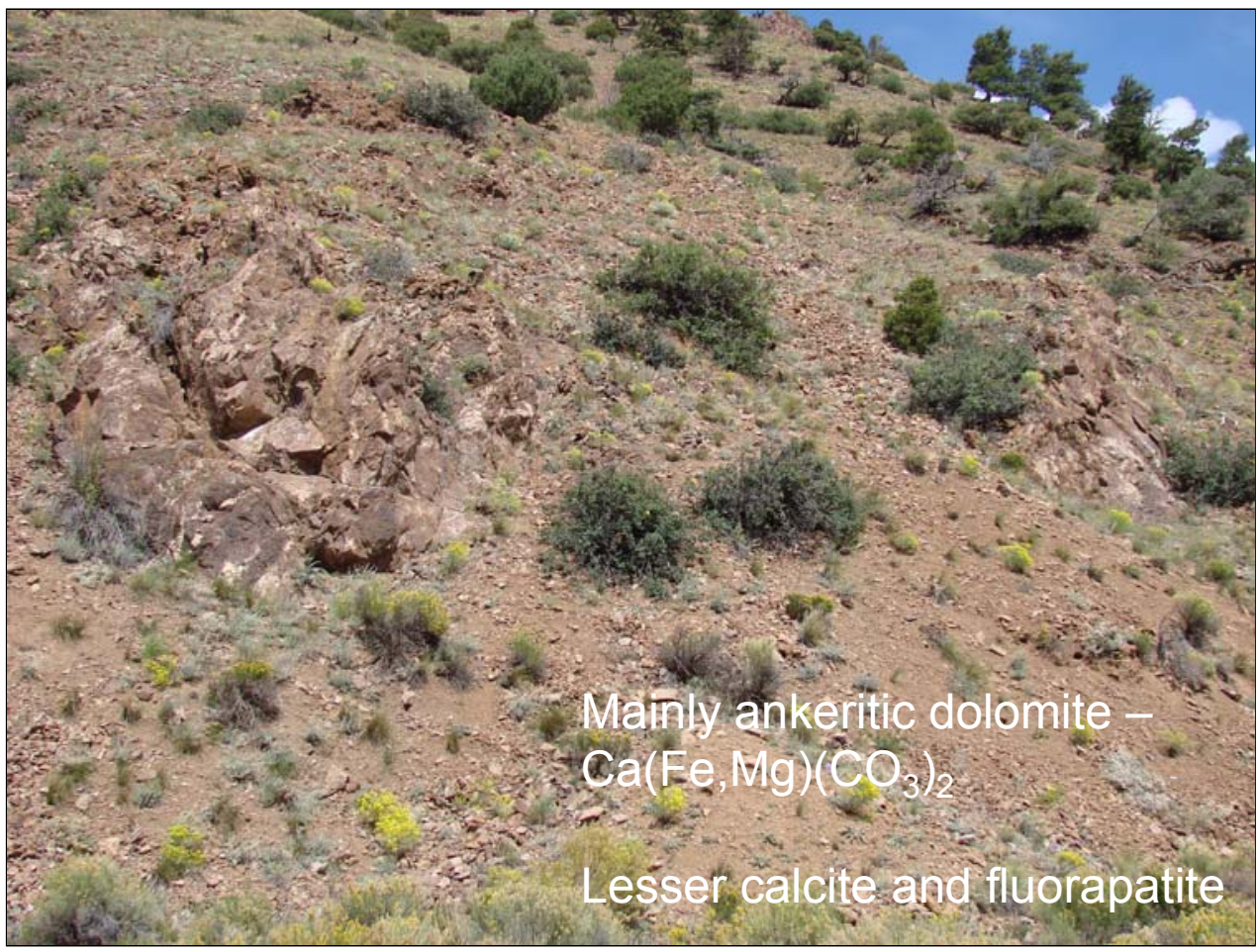

View of outcrops of the carbonatite stock exposed low on the southeast flank of Iron Hill. The Iron Hill carbonatite is composed primarily of ankeritic dolomite (iron-rich dolomite), and contains abundant but lesser amounts of calcite and fluorapatite. Samples of the outcrop on the left revealed $411 \mathrm{ppm}$ cerium and 816 ppm niobium. 


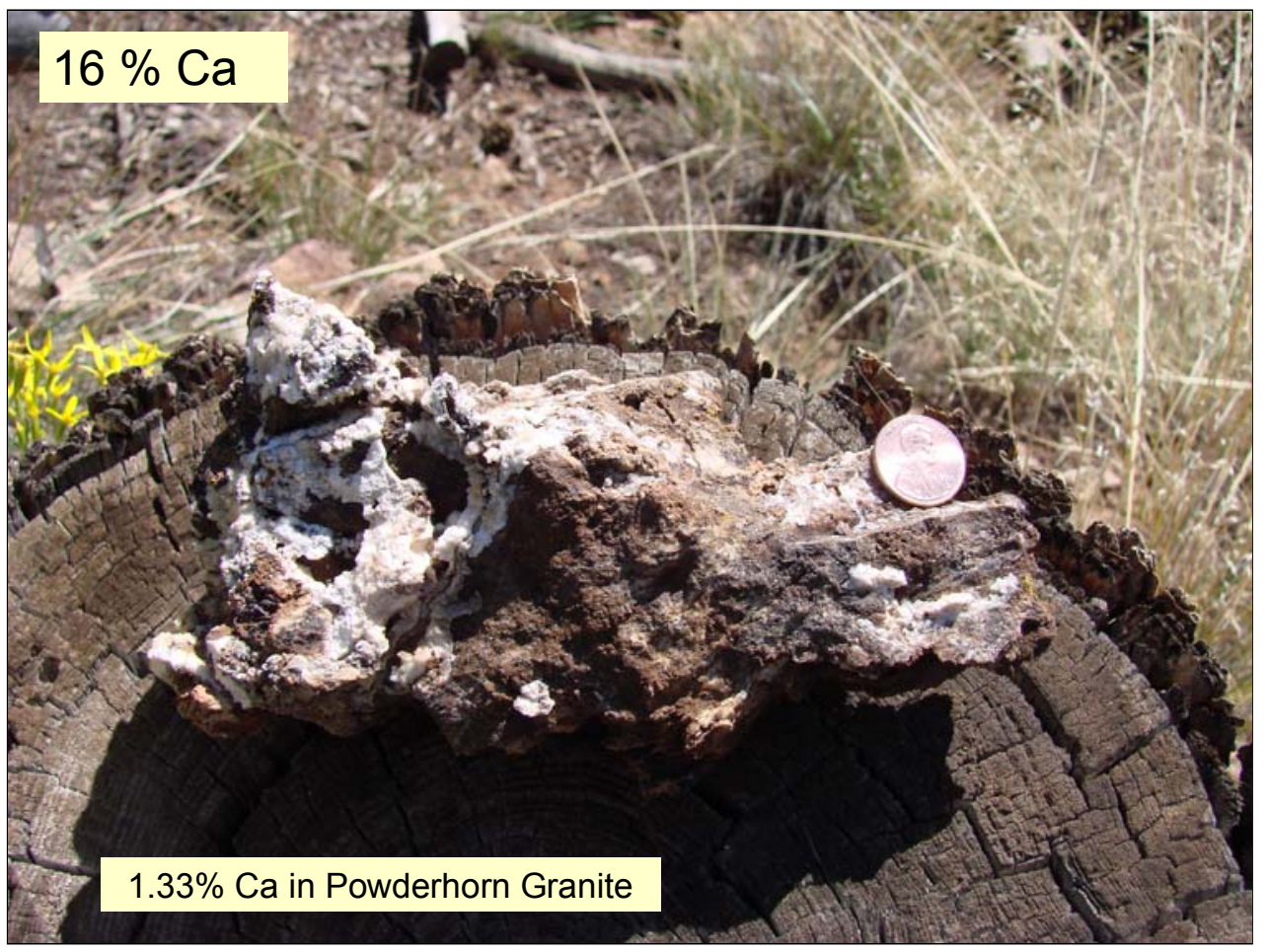

This sample of the Iron Hill carbonatite shows the very calcic nature of the stock (the white minerals are calcite). Sampling of the carbonatite stock (Van Gosen, 2008) found a median content of 16.1 percent calcium (13 samples). For comparison, the nearby Powderhorn Granite contains an average content of 1.33 percent calcium. 


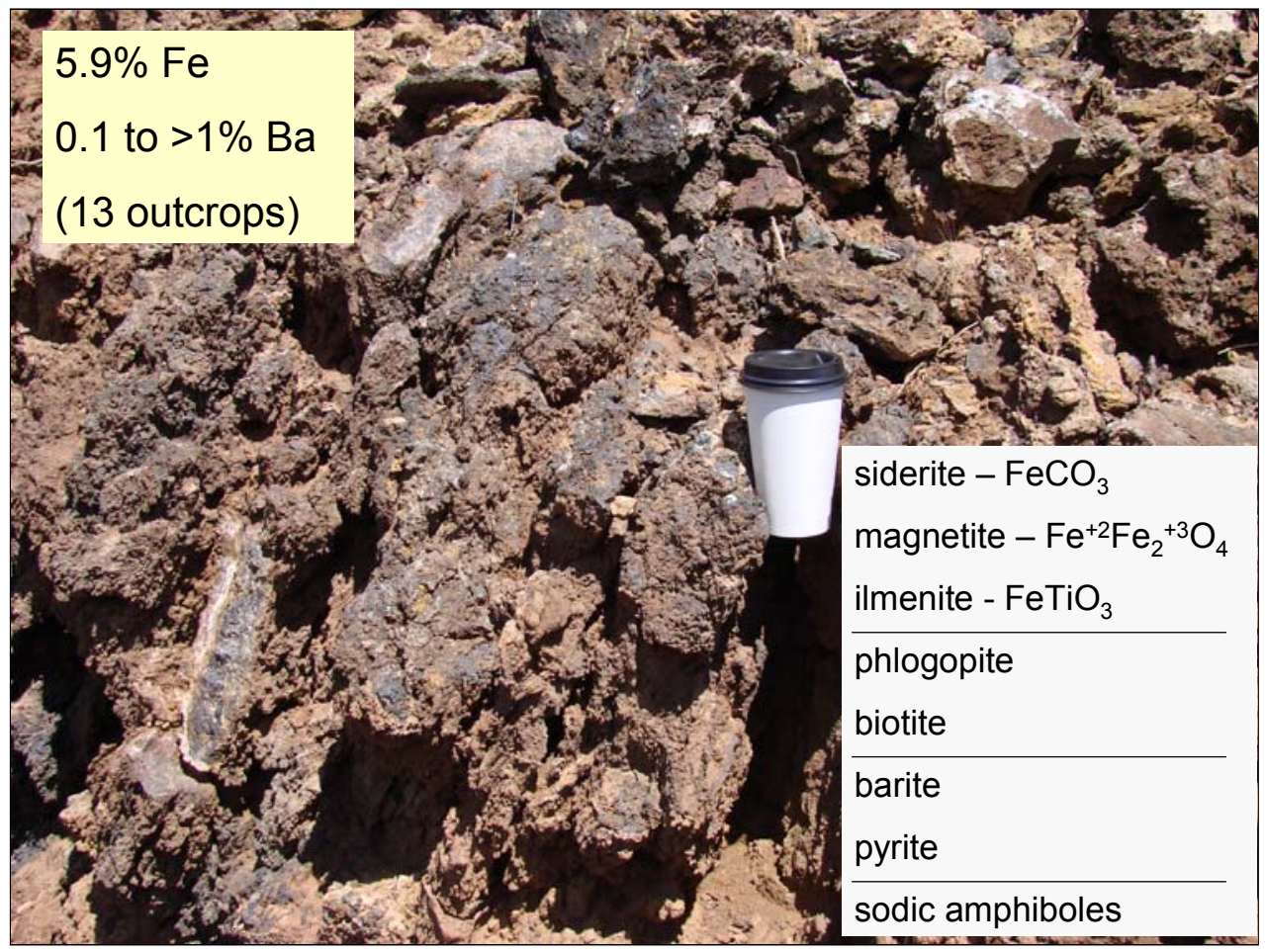

The Iron Hill carbonatite stock is also enriched in iron (median value of 5.9 percent iron, 13 samples) and barium ( 0.1 to more than 1 percent barium) (Van Gosen, 2008). Minor accessory minerals in the carbonatite include siderite, magnetite, ilmenite, phlogopite, biotite, and sodic amphiboles and trace amounts of pyrite. Barite can be abundant in parts of the stock, explaining the high concentrations of barium found in some samples. 


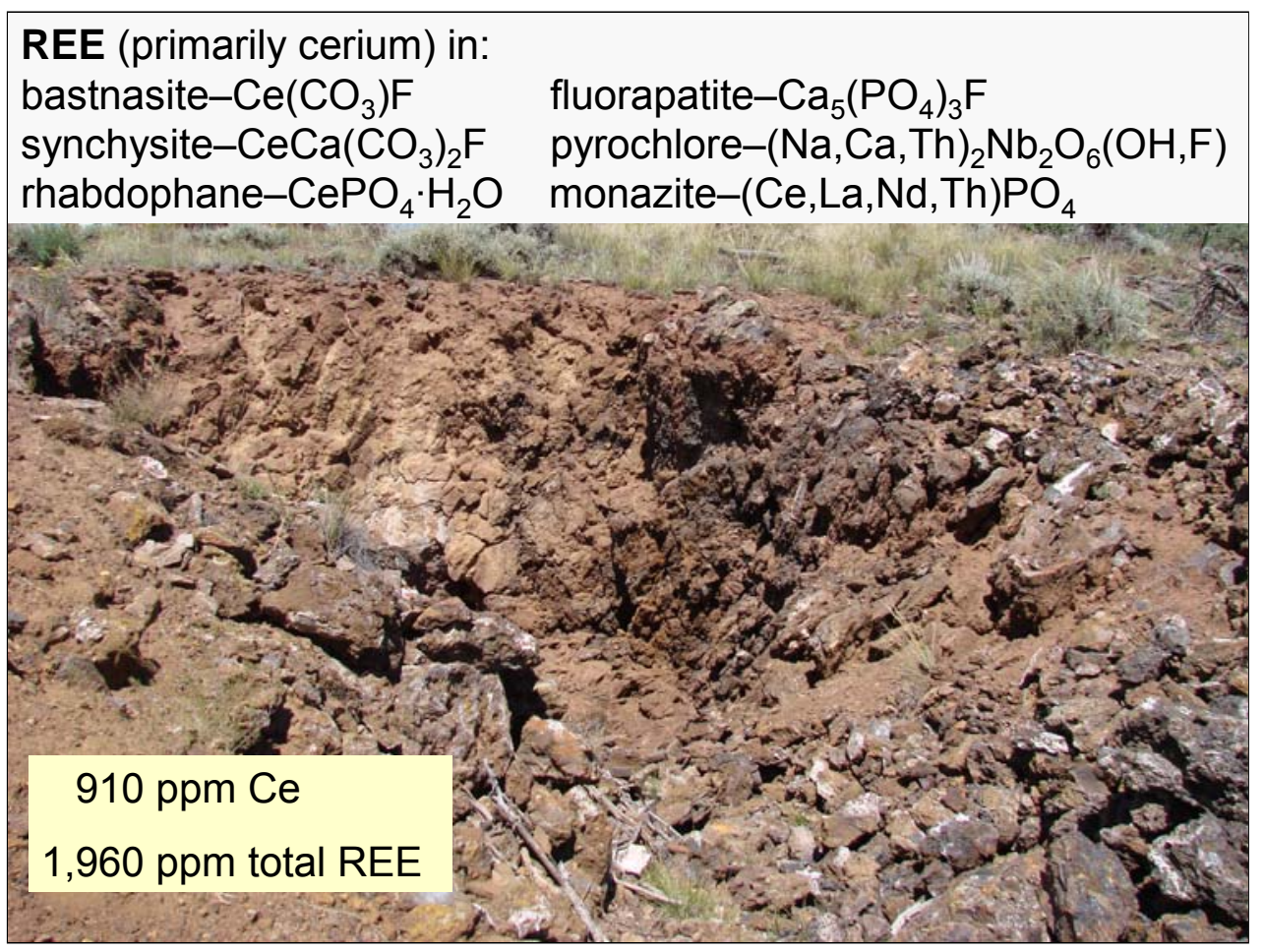

As is typical of carbonatites, the Iron Hill carbonatite stock is enriched in rare earth elements, particularly in cerium, a "light" rare earth element. Thirteen samples of the carbonatite contain median values of $910 \mathrm{ppm}$ cerium and 1,960 ppm total rare earth elements. These rare earth elements occur primarily in the minerals bastnasite, synchysite, and rhabdophane, and lesser amounts occur in fluorapatite, pyrochlore, and monazite. 


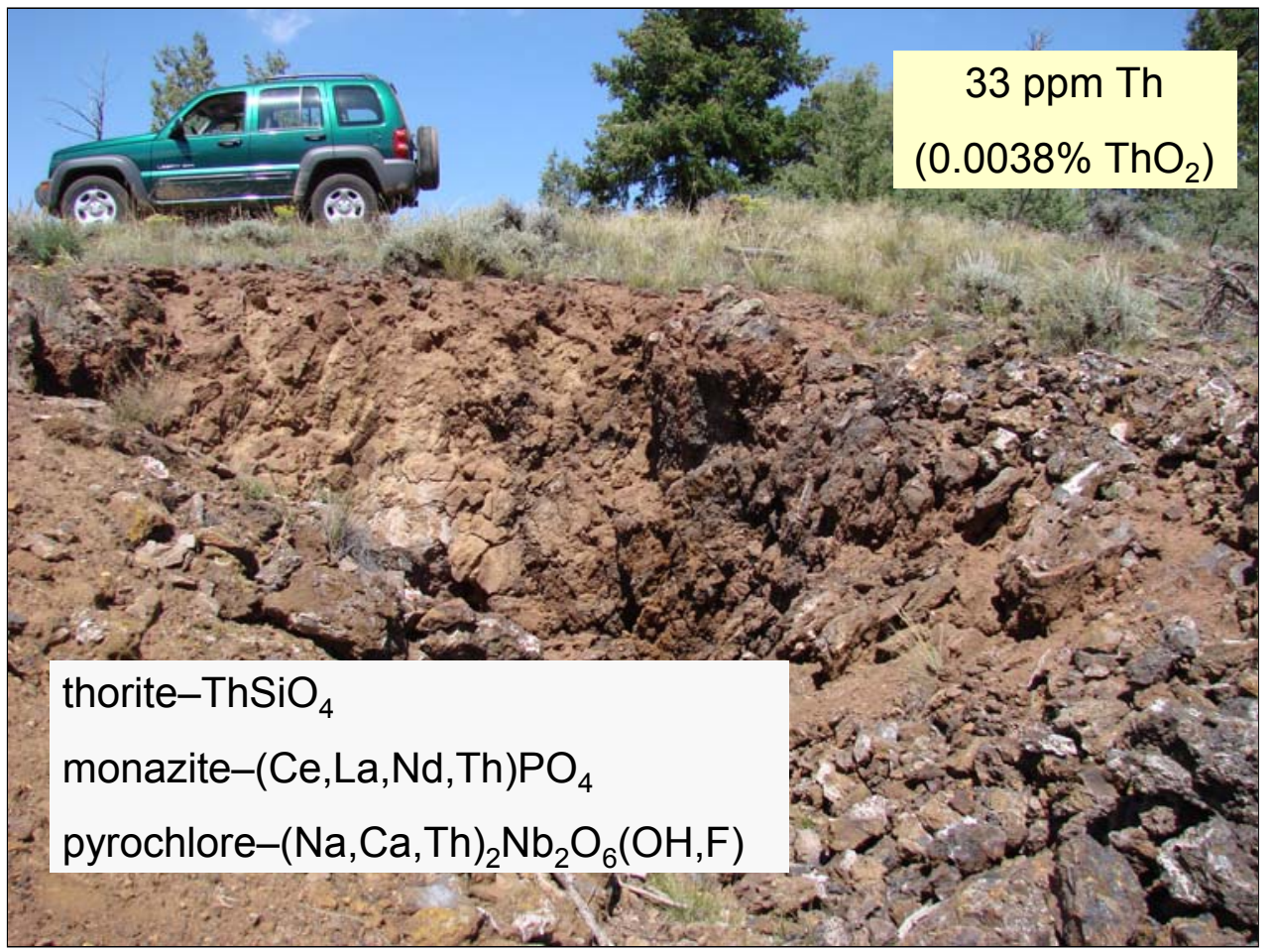

The Iron Hill carbonatite stock is anomalous in thorium (compared to "normal" igneous rocks), but not in impressive concentrations. Thirteen samples of the stock contain a median content of $33 \mathrm{ppm}$ thorium. The thorium occurs primarily in the mineral thorite, and to a lesser extent in monazite and pyrochlore. 


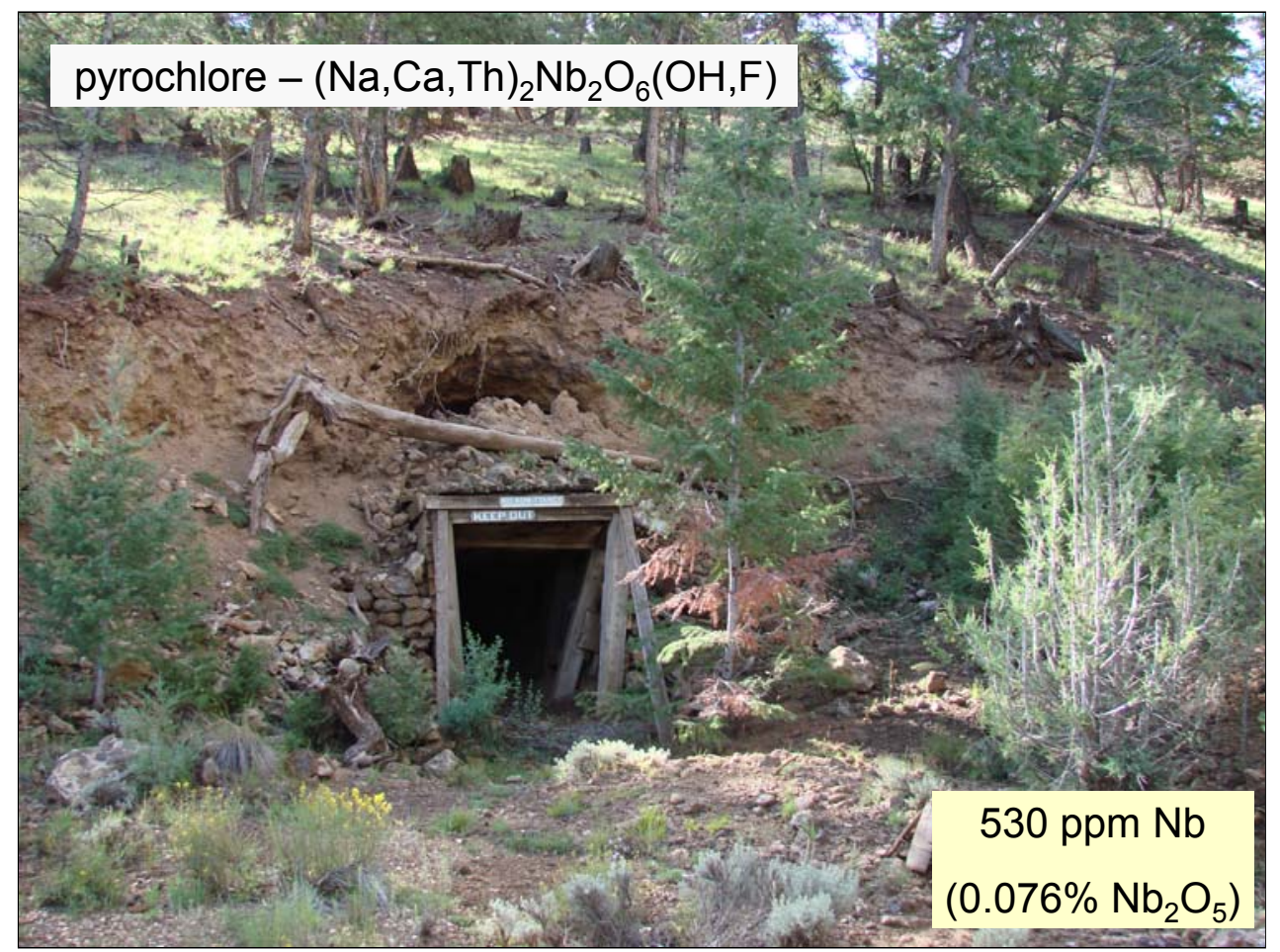

In 1956, Du Pont Corporation staked claims and acquired properties and mineral rights at Iron Hill. Du Pont's primary exploration focus was on the niobium resource potential of the carbonatite stock because they saw similarities to niobium-bearing carbonatites of the African continent. The abundance of pyrochlore in the Iron Hill stock, the primary host mineral for niobium, suggested a potential for large niobium resources within the stock. From 1957 into the early 1960s, Du Pont conducted exploration within the stock, which included core drilling and the excavation of this adit (the "Du Pont adit") to perform underground sampling. Unfortunately, none of the assay results from Du Pont's exploration at Iron Hill were published.

Thirteen samples of the carbonatite stock collected and analyzed by Van Gosen (2008) found a median concentration of 530 ppm niobium. 


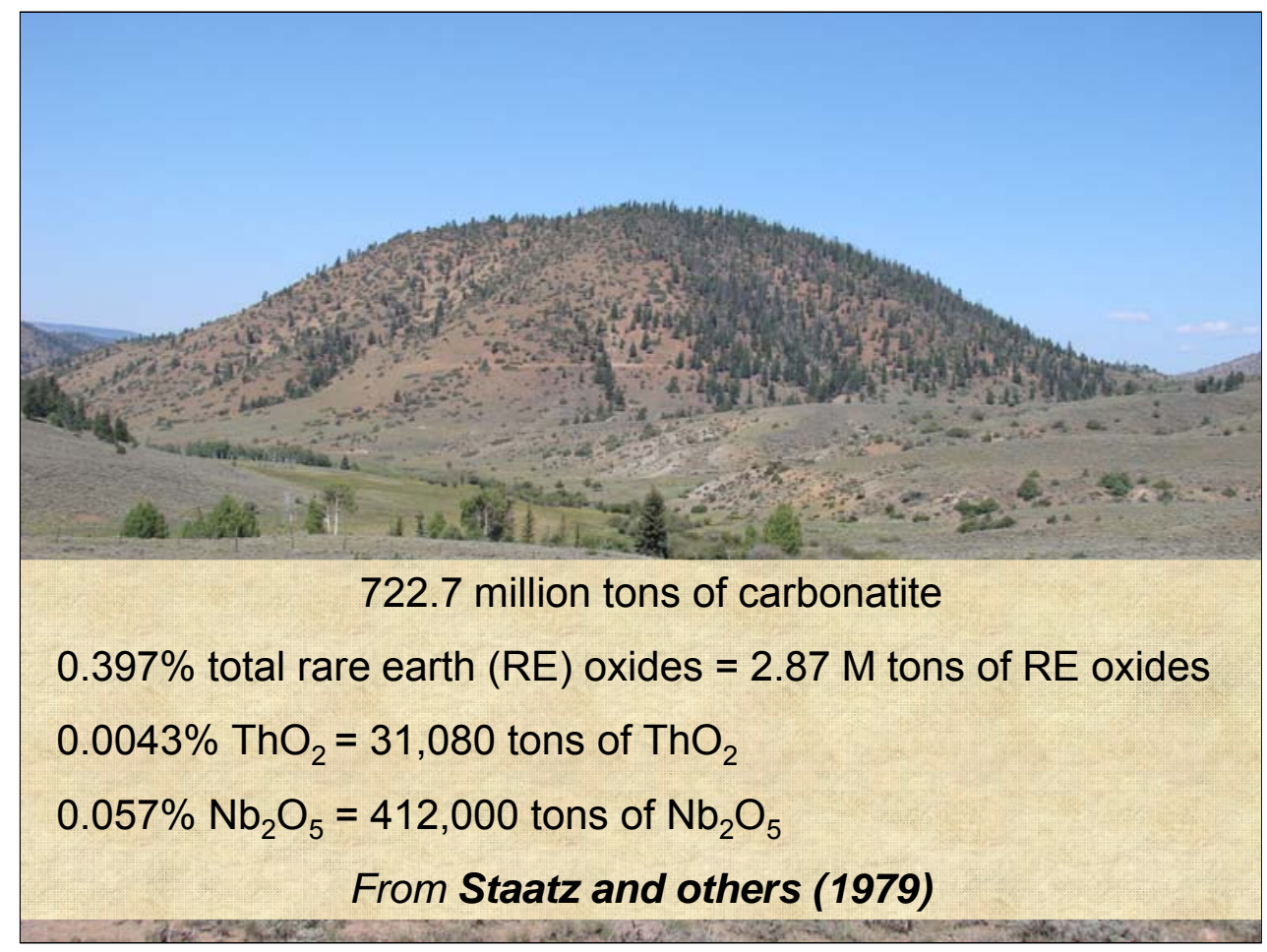

Staatz and others (1979) estimated that the carbonatite stock of Iron Hill contains 722.7 million short tons (655.6 metric tons) of carbonatite. Using average grades (shown above) that they obtained from their 28 samples of the carbonatite stock, they calculated potential reserves in the stock of 2.87 million short tons of rare earth oxides, 31,080 short tons of thorium oxide, and 412,000 short tons of niobium oxide. Geochemical analyses of 13 samples recently collected from the stock by Van Gosen (2008) found similar average concentrations for these elements. 


\section{Exploration History at Iron Hill}

- 1880s: The "Cebolla Creek iron deposit." Ti was considered an "objectionable material," which made processing of the iron ores impractical for the smelters of the day.

- 1940s to 1980s: USGS studies included geologic mapping, petrology, and geochemical analyses of the rock units that focused on their Th, REE, Nb, and Ti content.

- Late 1950s: U.S. Bureau of Mines drilling program to investigate the $\mathrm{Fe}$ and Ti resources in the pyroxenites. Estimates of $6.5 \% \mathrm{TiO}_{2}$ and $11.7 \% \mathrm{Fe}$ in a deposit of at least 100 million tons.

- 1956: Du Pont staked claims and acquired properties and mineral rights at Iron Hill. Extensive exploration for niobium (columbium) from 1957 into early 1960s, including drilling and excavation of an adit.

Brief summary of the exploration history at Iron Hill, Gunnison County, Colorado. See Van Gosen and Lowers (2007) for references that describe these events in more detail. 


\section{Exploration History at Iron Hill}

- 1968: Buttes Gas \& Oil Co. purchased the Iron Hill properties. They focused their exploration on $\mathrm{Ti}$ in the perovskite-rich pyroxenites on the northern side of the Cimarron fault. Explored the site into the 1980s. Estimated reserves of 390 million tons of rock averaging $11.5 \% \mathrm{TiO}_{2}$.

- 1990: Teck Resources entered into a joint venture with Butte Gas \& Oil Co. to explore for Ti at Iron Hill.

- 1994: Teck Resources purchased $100 \%$ interest in the properties. They reported "mineable" reserves of 46 million tons grading $13.2 \%$ $\mathrm{TiO}_{2}$ and a possible resource of 1.8 billion tons grading $10.9 \% \mathrm{TiO}_{2}$.

Brief summary of the exploration history at Iron Hill, Gunnison County, Colorado, continued. See Van Gosen and Lowers (2007) for references that describe these events in more detail. 


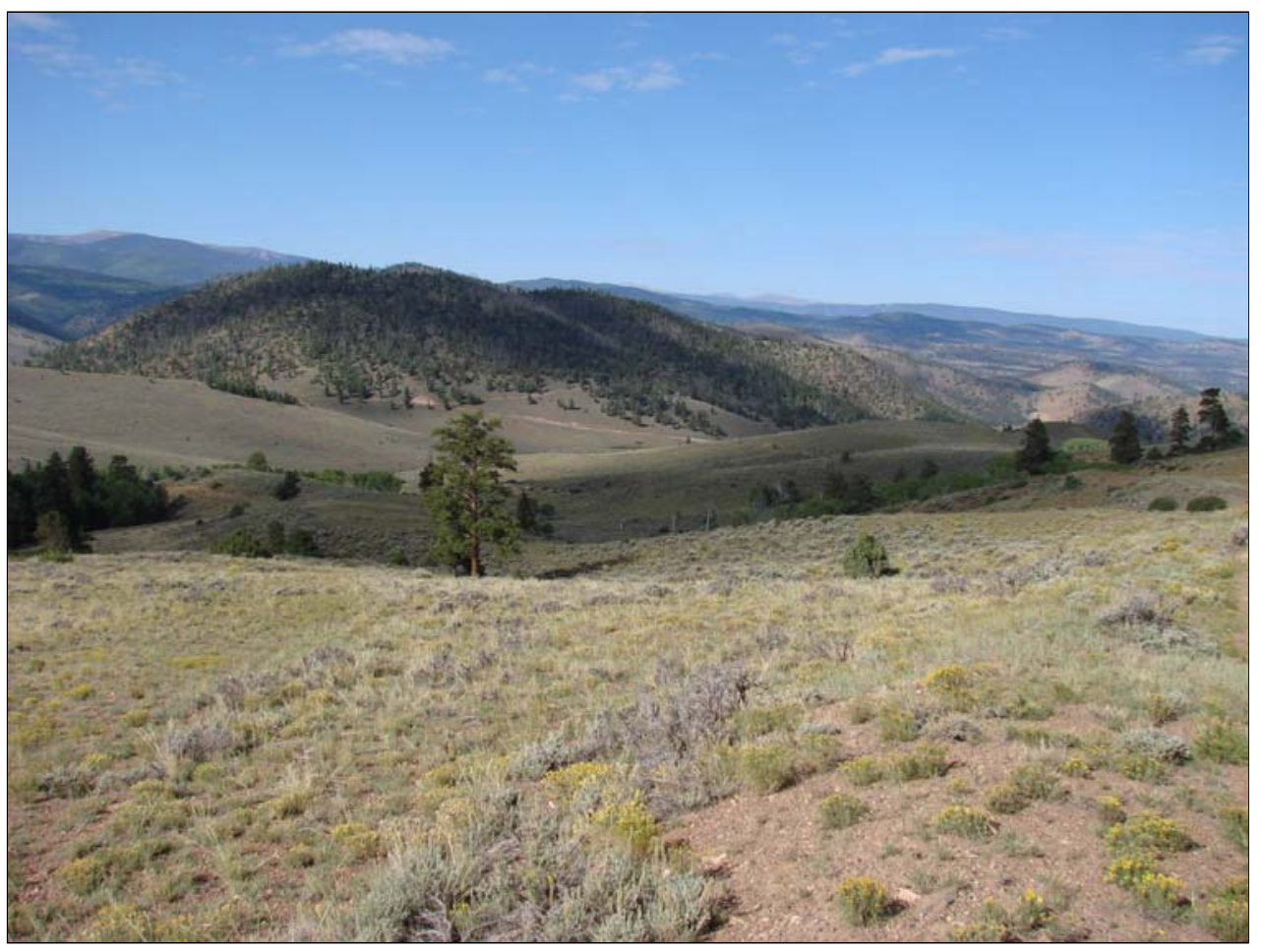

Despite its large deposits of titanium, niobium, and rare earth elements, thus far (2008) none of the mineral resources in the Iron Hill carbonatite complex have been developed. Van Gosen and Lowers (2007) provide a summary of the geology and mineral resources of this complex; this paper also cites more than two dozen references to previous investigations of this classic carbonatitealkaline intrusive complex. 


\section{References Cited}

- Hedlund, D.C., and Olson, J.C., 1975, Geologic map of the Powderhorn quadrangle, Gunnison and Saguache Counties, Colorado: U.S. Geological Survey Geologic Quadrangle Map GQ-1178, scale $1: 24,000$

- Olson, J.C., 1974, Geologic map of the Rudolph Hill quadrangle, Gunnison, Hinsdale, and Saguache Counties, Colorado: U.S. Geological Survey Geologic Quadrangle Map GQ-1177, scale $1: 24,000$

- Olson, J.C., and Hedlund, D.C., 1981, Alkalic rocks and resources of thorium and associated elements in the Powderhorn district, Gunnison County, Colorado: U.S. Geological Survey Professional Paper 1049-C, $34 \mathrm{p}$.

- Shaver, K.C., and Lunceford, R.A., 1998, White Earth project, Colorado-The largest titanium resource in the United States: Canadian Industrial Minerals Bulletin, v. 91, p. 63-65.

- $\quad$ Staatz, M.H., Armbrustmacher, T.J., Olson, J.C., Brownfield, I.K., Brock, M.R., Lemons, J.F., Jr., Coppa, L.V., and Clingan, B.V., 1979, Principal thorium resources in the United States: U.S.' Geological Survey Circular 805, 42 p.

- Thompson, J.V., 1987, Titanium resource in Colorado equals all other US deposits: Engineering and Mining Journal, v. 188, no. 7, p. 27-30.

- Van Gosen, B.S., 2008, Geochemistry of rock samples collected from the Iron Hill carbonatite complex, Gunnison County, Colorado: U.S. Geological Survey Open-File Report 2008-1119, 27 p. Available at http://pubs.usgs.gov/of/2008/1119/

- Van Gosen, B.S., and Lowers, H.A., 2007, Iron Hill (Powderhorn) carbonatite complex, Gunnison County, $\mathrm{CO}-\mathrm{A}$ potential source of several uncommon mineral resources: Mining Engineering, $v$. 59 , no. 10 , p. $56-62$. 
